\title{
THE TIME WINDOW FOR VESSELS WITHOUT ICE STRENGTHENING ON THE NORTHERN SEA ROUTE
}

\begin{abstract}
The work discusses possibility to make transit voyages of vessels without ice strengthening on the Northern Sea Route (NSR). Exist many uncertainties for it. They are related to hydro-meteorological conditions, mostly to ice cover on the Russian Arctic. Ice conditions are under dynamic changes in time and space. Is hard to precisely predict ice conditions now, in the time range of one month and so on. Statistical historical data of daily changes same like yearly changes show a considerable scatter of the data. The author analyzed number of ice-free days of particular seas of the NSR in the latest eight years. The results of this work may be used for estimation of time frame (time window) for transport of cargo on the NSR by means of vessels without ice strengthening. The statistical presentation of ice-free days data was used in the work to develop decision supporting method related to planning vessel voyage including ice-free time frame on particular seas of the Northern Sea Route.
\end{abstract}

\section{Keywords:}

Northern Sea Route, ice-free time frame, vessel voyage planning, sea transport, economical efficiency.

\section{INTRODUCTION}

Climate change is especially noticeable in recent years and responsible for the shrinking ice area in the Arctic. This is most visible in the Russian Arctic, along the so-called Northern Sea Route (NSR). In the winter the seas freeze over 
there completely. The NSR includes Kara Sea, Laptev Sea, East Siberian Sea and Chukchi Sea (Fig. 1).

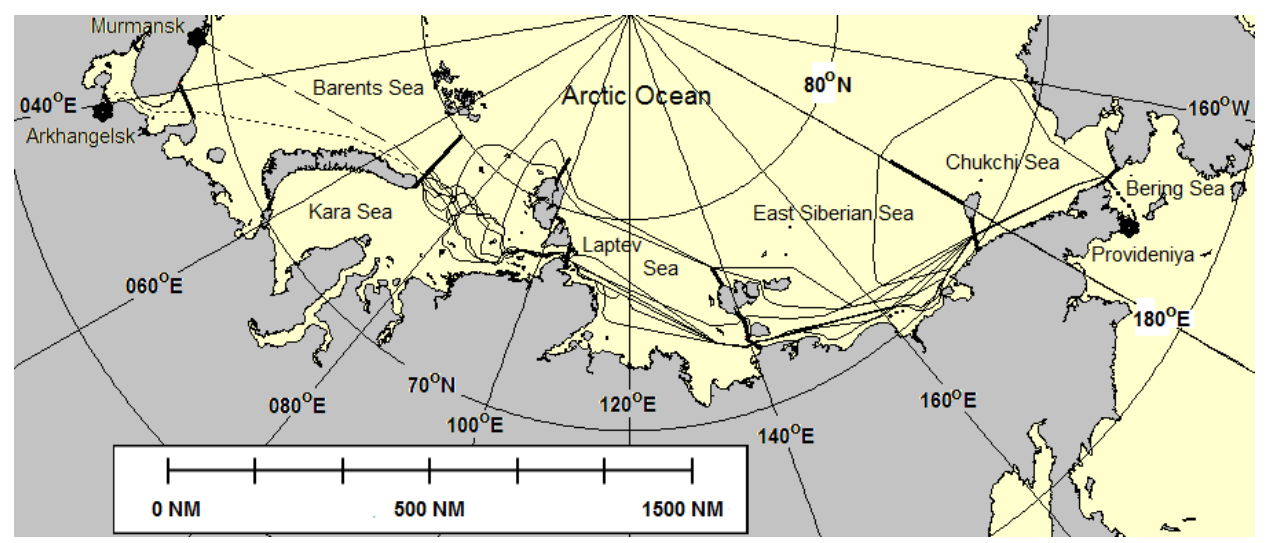

Fig. 1. The NSR and routes variants Eastward during ice-opening passages on 2008-2015: — routes Eastward on the NSR, _ — — route Murmansk — NSR, ‥ route Arkhangelsk - NSR, $\cdot-\cdot$ route Provideniya — NSR, _ limits of the seas [based on MIZ sea ice concentration maps in ESRI Shape format analysis, provided courtesy of the U.S. National Ice Center; base map made with Natural Earth free vector and raster map data, http://www.naturalearthdata.com]

To complete transit voyages through the NSR is necessary pass external seas. The Barents Sea is linking the NSR with ports of Murmansk and Arkhangelsk where vessels pass inspections before commencing voyages. The Bering Sea is linking the NSR with port of Provideniya where vessels pass same inspections. Elongation of the navigation season and the presence of lighter ice conditions than in previous years encourages the use of vessels with low ice classes and vessels without ice-strengthened hulls in the summer season on this route. To plan travel schedule of such vessels one must have accurate information about the state of the ice cover ahead of several months, a few weeks, a few days, one day, and so on. Here, however, there is a lot of uncertainty. Forecasts lasting several months may not predict the difficulties of navigation in ice that would make impossible to complete successful voyage [Pastusiak, 2016e]. The variety of route options causes relatively small differences in length amounting to $3 \%$ of the total length of the route [Pastusiak, 2016b]. If the vessel decides to perform voyage directly after ice-free passage zone is open in the ice cover, the course is uncertain, frequently changed and the distance of passage increases. These 
routes in the way Eastward on 2008-2015 years presented on Figure 1. Except typical volatility of routes each year vessel may experience unexpected statistically blocked areas of seas by ice. It require change voyage plan. Two times, instead to pass through Severnaya Zemlya archipelago straits, route passed the archipelago from the North. One time, blocked large area by ice required come back from vicinity of port at Pevek and pass to North around Wrangel Island towards Alaskan coast and then towards Bering Strait. Current information on ice cover give ice maps made from satellite remote sensing observations. Dispersion of position of individual ice characteristics given by various data sources is large [Pastusiak, 2016a], [Pastusiak, 2016d], [Pastusiak, 2016c], [Pastusiak, 2015]. Per example, the spatial dispersion band of $40 \%$ ice concentration limit found about $40 \mathrm{NM}$. It is $80 \%$ of total zone of not completely compacted ice (Mariginal Ice Zone MIZ). Dilution of position, that includes resolution of map, time interval in between consecutive publication of information and delay of publication of information in relation to time of reference of data source was found between 13 and $51 \mathrm{NM}$.

\section{PURPOSE AND SCOPE OF THE STUDY}

Vessels with ice-strengthened hulls (with ice classes) are relatively expensive in construction and less competitive on the World shipping market than vessels without ice-strengthened hulls [Pastusiak, 2016e]. The vessels without ice class are less expensive that make them more economical. But they are very sensitive to the existing ice along the NSR. The large and unexpected changes of ice conditions in space and time (p. ex. different difficult regions every year, different time of ice-free passage zones opening every year and so on) may make voyages without ice-strengthening not economical due to long time under charter awaiting for ice free passage or due to unsuccessful voyage in case ice-free passage zone was closed before vessel passed the whole NSR. The additional possible costs of icebreaker assistance make additional costs and reduce economical results of the voyage. Due to above uncertainties is hard to plan successful voyages of the vessels without ice-strengthening.

The goal of this work is to solve the problem of route planning under uncertain ice conditions on the NSR. The hypothesis was placed that is possible to make the method of planning schedule of consecutive transit voyages of the vessel without ice-strengthening through the NSR. The initial voyage planning, 
that covers the period from 6 months till 1 month before commencement of navigation season, should include statistical data. These statistics should include period of last years of accelerated climate change and reduction of ice cover in the Arctic. The ice data should be reliable in relation to ice conditions affecting the ice limitations of the vessels without ice-strengthening.

\section{RESEARCH METHOD}

The Northern Sea Route divided into regions. There are seas lying along the route as natural basins of individual specifics. To this chain added external basins: Barents and Bering Sea. Vessel must pass through these seas to enter the NSR. The Barents and Bering seas are partly covered by ice during each winter season that is blocking attempt to the NSR.

The climate changes systematically accelerating since 1900 year. The statistical data should be enough long to avoid misleading due to short term anomalies from the trend. Assumed, the old historical statistics before the year 2000 will not represent well the actual ice conditions due to accelerated climate changes last years. In this case statistical data should contain latest 5-10 years.

Main question was reliability of ice maps. These maps should be available for whole Russian Arctic. They should show reliable ice concentration limits that are key constraints for traffic of vessels of low ice class or without ice strengthening. The data should be presented in form of maps of any format. Due to dilution of position error [Pastusiak, 2016d] that deteriorated synthetic quality index, the data sources should be published on daily basis. Previous works of the author in this subject [Pastusiak, 2016a], [Pastusiak, 2016d], [Pastusiak, 2016c] and [Pastusiak, 2015] determined two data sources. There are maps of computational predictions of ice concentration in the Arctic Ocean of the AARI in the form of isolines in raster format (http://ocean8x.aari.nw.ru/index.php?id=600\&-model=3) and maps of ice floes concentration in a simplified Marginal Ice Zone (MIZ) scale in the Arctic Ocean of the NIC in georeferenced vector ERSI Shape format (http://www.natice.noaa.gov/products/daily_products.html) presented in earlier work [Pastusiak, 2016c]. Finally decided to use U.S. National Ice Services maps in simplified ice concentration scale because theirs spatial distribution of ice was verified by the author during field observations [Pastusiak, 2015] and more detailed presentation of ice floe concentration isolines. 
The vessels without ice strengthening require 'ice-free' zone for safe and efficient passage. This is a little different meaning than 'ice-free sea area' implemented by Rodrigues [Pastusiak, 2016e], [Rodrigues, 2008], [Rodrigues, 2009]. The 'ice-free' passage zone defined by the author it is zone of ice concentration below 15-25\%. In case of used in the work ice maps, the areas out of MIZ zone of concentration below 18\% should be accepted [Pastusiak 2016e], [Rodrigues, 2008], [Rodrigues, 2009], [ACIA, 2005], [Dremlyug, 1974], [Petrov, 1955].

First, the results of analysis divided into days of the year when the ice-covered particular sea opened ice-free passage zone and into days when the particular sea close ice-free passage zone through the whole sea. Next, the results of ice maps analysis were divided by the region (particular sea of the NSR) and values representing the groups of average of statistical data (day of the year), minimal value in the group, maximal value in the group, average value decreased by standard deviation and average value increased by standard deviation. This division was implemented in earlier work of the author [Pastusiak, 2016c]. Assumed, the decision-maker should operate with more elastic parameter of ice conditions than average value and standard deviation multiple discrete changes. In this case continuous changes of the value were preferred instead of discrete changes. This capability possessed function of cumulative distribution. It included average value, standard deviation and value of reference for result of analysis (day of the year). This cumulative distribution presented on diagram contains day of the year of opening or closing ice-free passage zone through the particular sea and the probability of exceeding/not exceeding the indicated day of the year.

\section{RESULTS}

The dates of first and last day of ice-free passage zone for particular seas were determined from the analysis of the daily maps of ice cover for the years 2008-2015. Following Rodrigues [Rodrigues, 2008], [Rodrigues, 2009] taken the method to trigger the day of change of ice conditions from ice-closed to ice-free and vice versa [Pastusiak, 2016e]. In case the ice-closed days were at the moment, the fifth consecutive day of opposite ice conditions (ice-free) were required to trigger towards ice-free day. The fifth day was confirmation of the change. In case the ice-opened days were at the moment, the fifth consecutive day of opposite ice conditions (ice-closed) were required to trigger towards ice-closed day. The fifth 
day was confirmation of the change. The average values and standard deviation $\sigma$ were calculated. As the rule, maximal and minimal values of the dates were outside the band od average value $\pm \sigma$ (Tab. 1 and 2). The only one exception was minimal value for last day of ice-free passage zone on the Barents Sea (Tab. 2). It means, statistical data represented by average value and standard deviation values do not cover real range of ice-free passage zone time frame (time window). In this case, the use of cumulative distribution function as a probabilistic method in the evaluation of the possibility of vessel passage in the ice-covered regions seem to be more flexible, more synthetic in use and retaining continuous variation of studied parameters than the method of average value and multiple discrete changes of standard deviation.

Tab. 1. First day of ice-free passage zone available on the particular region of the NSR [based on MIZ sea ice concentration maps in ESRI Shape format analysis]

\begin{tabular}{|c|c|c|c|c|c|}
\hline Region of the NSR & Minimal & Average $-\sigma$ & Average & Average $+\sigma$ & Maximal \\
\hline Barents Sea & 111 & 149 & 166 & 182 & 190 \\
\hline Kara Sea & 217 & 219 & 241 & 263 & 286 \\
\hline Laptev Sea & 217 & 226 & 243 & 260 & 270 \\
\hline East Siberian Sea & 211 & 221 & 242 & 263 & 277 \\
\hline Chukchi Sea & 204 & 208 & 225 & 243 & 251 \\
\hline Bering Sea & 146 & 151 & 161 & 170 & 178 \\
\hline
\end{tabular}

Tab. 2. Last day of ice-free passage zone available on the particular region of the NSR [based on MIZ sea ice concentration maps in ESRI Shape format analysis]

\begin{tabular}{|c|c|c|c|c|c|}
\hline Region of the NSR & Minimal & Average $-\sigma$ & Average & Average $+\sigma$ & Maximal \\
\hline Barents Sea & 340 & 336 & 376 & 415 & 448 \\
\hline Kara Sea & 273 & 277 & 287 & 298 & 299 \\
\hline Laptev Sea & 250 & 263 & 280 & 296 & 299 \\
\hline East Siberian Sea & 282 & 287 & 291 & 294 & 295 \\
\hline Chukchi Sea & 294 & 298 & 312 & 326 & 338 \\
\hline Bering Sea & 326 & 328 & 341 & 353 & 358 \\
\hline
\end{tabular}

Next, the cumulative distributions of first day and reversed cumulative distributions of last day of ice-free passage zone available on the particular region of the NSR were calculated (Fig. 2 and 3). From the diagram in Figure 2 can be 
determined probability of occurrence of an ice-free area connecting two adjacent seas in a given NSR region during the decay of ice cover period on the day not later as indicated for this NSR region. With a probability of $50 \%$ will be already free of ice passage on the following seas: Bering (day 160), Barents (day 166), Chukchi (day 226), Kara (day 241), East Siberian (day 242) and the Laptev (day 243). The probability of occurrence of ice-free zone will be the higher the later the day of the year will be taken into account.

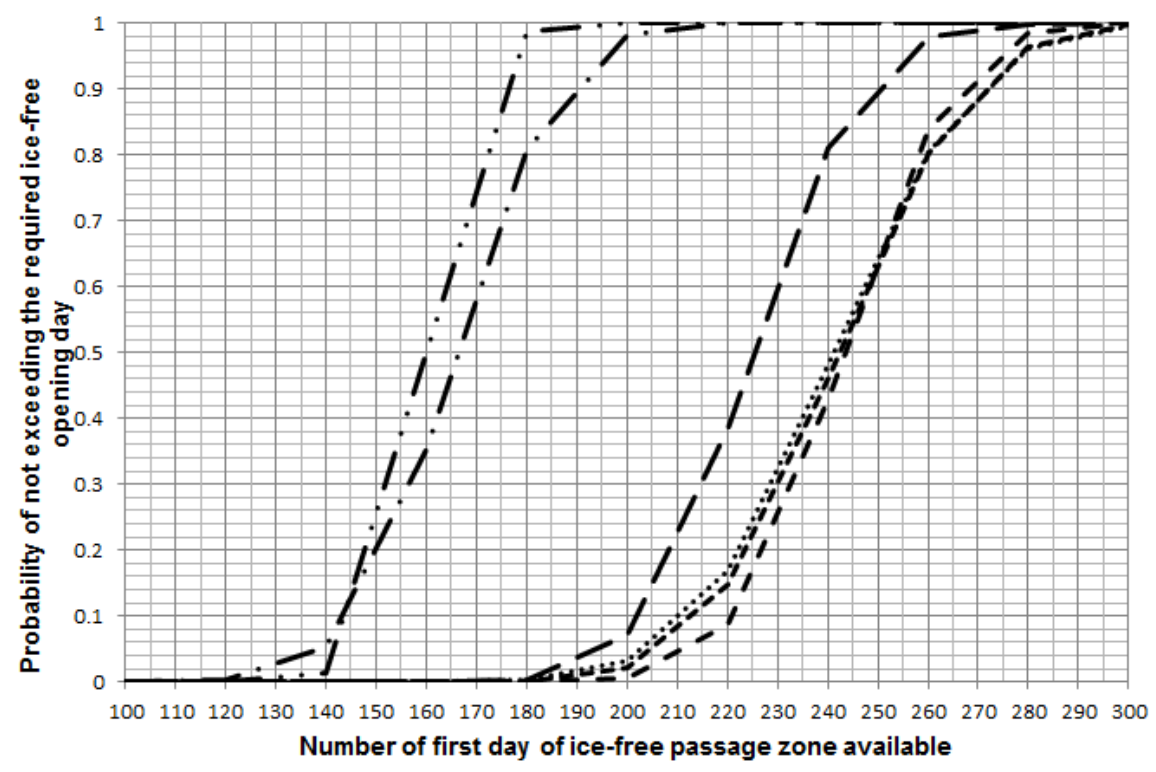

Fig. 2. Cumulative distributions of first day of ice-free passage zone available on the particular region of the NSR: - - Kara Sea, - - - East Siberian Sea,

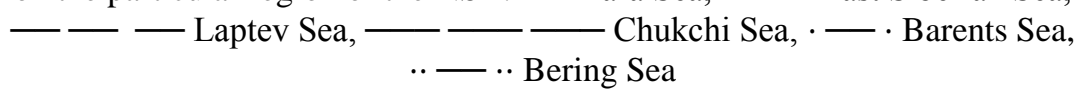

From the diagram in Figure 3 can be determined the probability of occurrence in a given NSR region, during the development (built-up) of ice cover, of the ice-free zone connecting the two adjacent seas on the day not later as indicated for this NSR region. With a probability of $50 \%$ will still be free of ice passage on the following seas: the Laptev (day 278), Kara (day 285), East Siberian (day 294), Chukchi (day 310), Bering (day 338), Barents (day 375). The figure exceeds 365 (366) days means that the end of the season will take place in the next calendar year. The probability of occurrence of ice-free zone will be the higher the earlier day of the year will be taken into account. 


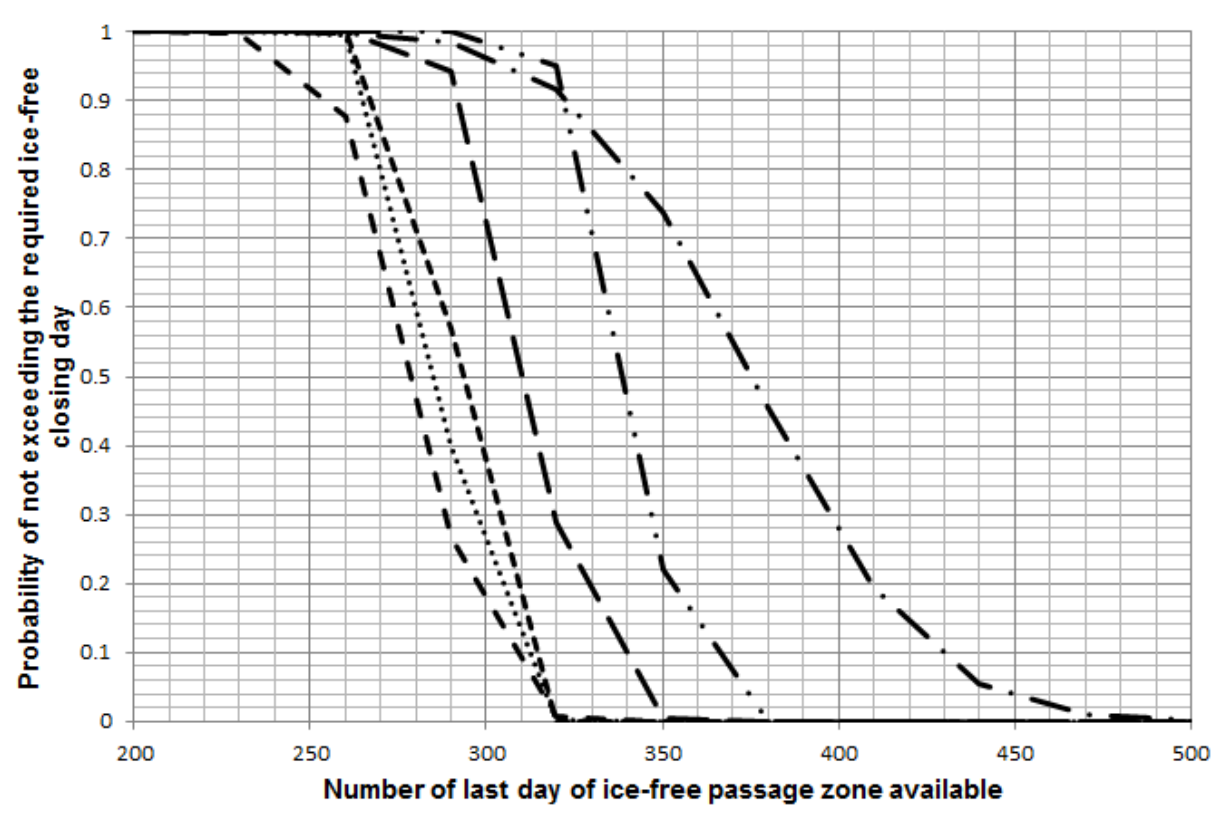

Fig. 3. Reversed cumulative distributions of last day of ice-free passage zone available on the particular region of the NSR: - . Kara Sea, - - East Siberian Sea, - — - Laptev Sea, —— Chukchi Sea, $-\longrightarrow$ B Barents Sea, -. - * Bering Sea

It should take into account that the period of time of ice-free for a particular sea can be very limited. For example, the cumulative distributions for the first and last day of occurrence of ice-free passage zone (Fig. 4) on the Laptev Sea overlap each other, even in the zone with a high slope of the curves (in the vicinity of the middle of the curve). If the person taking the decision on deadlines for intended voyage will require a very high level of confidence (probability) of the first day of ice-free zone, it also meets a very high level of probability of occurrence of the last day of ice-free zone. This means that in the ice conditions occurring in the last eight years (2008 to 2015) scheduling the time of voyages will always involve numerous risks of necessity of waiting at sea before the onset of ice-free passage zone, the slow movement of vessel in the general direction of destination according to the ongoing development of ice-free passage zone or catch an option not to leave the region before the closure office-free zone. This concerns in particular the Laptev Sea, Kara Sea and East Siberian Sea. If the vessel does not have time to leave the areas of ice cover growth before closing by ice, the solution can be risky 
to continue movement in ice of higher level of ice characteristic than acceptable for the vessel or expensive icebreaker assistance. On the cumulative distribution graph for the Laptev Sea (Fig. 4) is visible probability of $83 \%$ risk of not encountering ice-free passage zone.

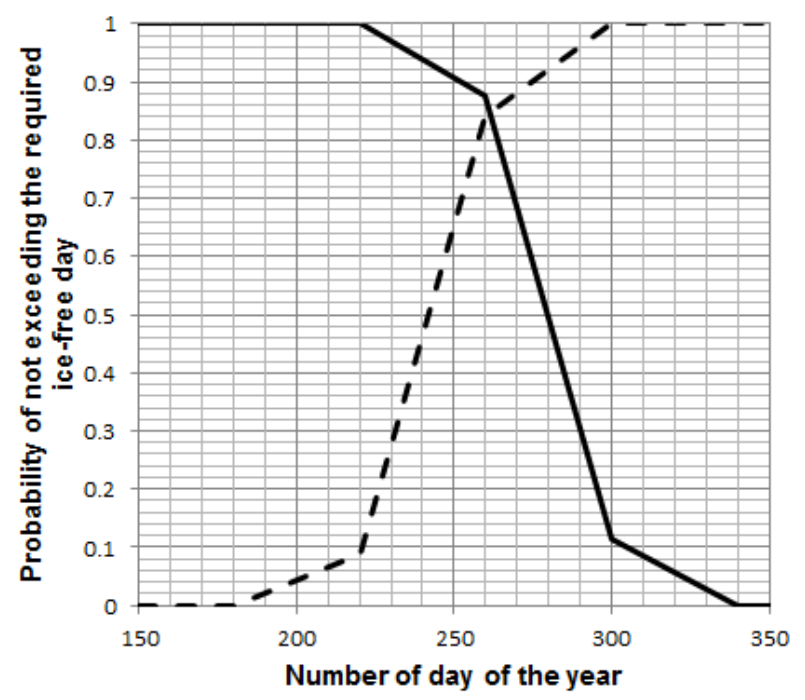

Fig. 4. Time frame in between first and last day of ice-free passage zone on Laptev Sea: - - opening (first) day, $\_$closing (last) day

Planned trips relate to passage of vessel that does not have ice-strengthened hull by the NSR Eastward from Murmansk to Provideniya and back, Westward from Provideniya to Murmansk in one navigation season. Assumed that the results should be similar for the port of Murmansk and for the port of Arkhangelsk. It was also assumed that safe speed of vessel in areas where is a significant number of days beyond the influence of ice cover (the Barents Sea and the Bering Sea in a later stage of ice cover decay on the NSR) may be close to the maximum possible. After taking into account the speed reduction due to the present conditions of bad weather let is 16 knots. The speed of such a vessel in the regions in which just opened ice-free passage zone should be for safety reasons limited to 12 knots [Pastusiak, 2016e], [Petrov, 1955]. For probability 67\% on diagram at Figure 2 one can read the dates of beginning of ice-free zone at nodal points as follow: Cape Zhelanya on day 172, Vilkitsky Strait on day 252, Laptev Strait on day 252, De Long Strait on day 233, Bering Strait on day 167. That means the planned 
voyage Eastward commenced on day 252. Same day all next seas have ice-free zone through them. The same way, on diagram at Figure 3 one can read the closing dates of ice-free zone at nodal points as follow: Cape Zhelanya on day 357, Vilkitsky Strait on day 276, Laptev Strait on day 271 from Laptev Sea side and on day 283 from East Siberian Sea side, De Long Strait on day 302, Bering Strait on day 332.

Assumed, that vessel without ice-strengthened hull do not enters the ice-covered zone. Such a zone on ice maps will be identified by boundary of Mariginal Ice Zone with a concentration of ice from 10 to $18 \%$. Adopted standard distances of routes in line with the development of ice-free passage zones shown in Figure 1 in the last eight years (from 2008 to 2015). Knowing the length of particular route sections in the given NSR region and assigned to it the speed of the vessel, the transition time of individual sections can be planned. The mean square error position $1 \mathrm{M}$ previously used in Navigation met the criteria for the probability of $67 \%$. Such probability value taken for analysis. Assumed that the voyage commence from initial port, when the first NSR sea from this site will have an ice-free passage zone to the next sea. Table 3 shows the results of voyage planning with specified date (day number of the year) of vessel passage at the key (or nodal) route points. Total time of two consecutive voyages, first Eastward and second Westward including port and cargo operations time was equal 21.5 days. The ending day of planned voyages was 273 .

In case of reversed planned voyage, first Westward and second Eastward, under same criteria the voyage should commence on day 233. The results presented in Table 4. Assumed the vessel did not entered next region (not passed De Long Strait) until in the whole East Siberian Sea appeared to have ice-free zone passage to the next sea. On 234 day vessel arrived at the De Long Strait but was waiting till 252 day. This day all next seas had ice-free zone through them. Total time of two consecutive voyages commenced Eastward was equal 21.5 days and commenced Westward 22.8 days. The ending day of first option of planned voyages was 273.5 and second option was 255.8 .

In both cases the time of voyage (or Charter time) was very close. The second option of planned voyages (first Westward, second Eastward) completed earlier than first option (first Eastward, second Westward). It looks be good opportunity to continue consecutive voyages of second option and plan to complete three or four consecutive voyages, depending on closing day of any required for completion of voyage nodal point. 
This allows to plan future voyages taking into account the speed of the vessel, time spent on port operations and cargo handling, and the probability of favorable and unfavorable conditions of intended voyage. Using the described method decision-maker can plan the consecutive transit voyages through the NSR according to their knowledge, experiences and information on the current and forecasted state of ice cover in a calendar year.

Tab. 3. Schedule of planned voyages under option 'first leg Eastward'

\begin{tabular}{|c|c|c|c|c|c|}
\hline \multicolumn{6}{|c|}{ First leg (Eastward) — Distance 3,128 NM } \\
\hline & Distance & $\begin{array}{c}\text { Planned } \\
\text { speed } \\
{[\text { knots }]}\end{array}$ & $\begin{array}{c}\text { Days } \\
\text { of passage }\end{array}$ & $\begin{array}{c}\text { Arrival date } \\
\text { of passage } \\
\text { [number of day] }\end{array}$ & $\begin{array}{l}\text { The day closing } \\
\text { ice-free passage } \\
\text { [number of day] }\end{array}$ \\
\hline $\begin{array}{l}\text { Departure } \\
\text { from Murmansk }\end{array}$ & & & & 252.0 & \\
\hline Cape Zhelanya & 780 & 16 & 2.03 & 254.0 & 357 \\
\hline Vilkitsky Strait & 599 & 12 & 2.08 & 256.1 & 276 \\
\hline Laptev Strait & 618 & 12 & 2.15 & 258.2 & 271 \\
\hline De Long Strait & 748 & 12 & 2.60 & 260.8 & 302 \\
\hline Bering Strait & 213 & 12 & 0.74 & 261.5 & 332 \\
\hline Arrival at Providenya & 170 & 16 & 0.44 & 261.9 & \\
\hline \multicolumn{3}{|c|}{ Port and cargo operations [days] } & 3 & & \\
\hline \multicolumn{6}{|c|}{ Second leg (Westward) - Distance 3,128 NM } \\
\hline & Distance & $\begin{array}{c}\text { Planned } \\
\text { speed } \\
\text { [knots }]\end{array}$ & $\begin{array}{c}\text { Days } \\
\text { of passage }\end{array}$ & $\begin{array}{c}\text { Arrival date } \\
\text { of passage } \\
\text { [number of day] }\end{array}$ & $\begin{array}{l}\text { The day closing } \\
\text { ice-free passage } \\
\text { [number of day] }\end{array}$ \\
\hline $\begin{array}{l}\text { Departure } \\
\text { from Providenya }\end{array}$ & & & & 264.9 & \\
\hline Bering Strait & 170 & 16 & 0.44 & 265.3 & 332 \\
\hline De Long Strait & 213 & 12 & 0.74 & 266.0 & 302 \\
\hline Laptev Strait & 748 & 12 & 2.60 & 268.6 & 271 \\
\hline Vilkitsky Strait & 618 & 12 & 2.15 & 270.7 & 276 \\
\hline Cape Zhelanya & 599 & 12 & 2.08 & 272.8 & 357 \\
\hline Arrival at Murmansk & 252 & 16 & 0.66 & 273.5 & \\
\hline
\end{tabular}


Tab. 4. Results of planned voyages under option 'first leg Westward'

\begin{tabular}{|c|c|c|c|c|c|}
\hline \multicolumn{6}{|c|}{ First leg (Westward) - Total distance $3128 \mathrm{NM}$} \\
\hline Location & Distance & $\begin{array}{c}\text { Planned } \\
\text { speed } \\
\text { [knots] }\end{array}$ & $\begin{array}{c}\text { Days } \\
\text { of passage }\end{array}$ & $\begin{array}{c}\text { Arrival date } \\
\text { of passage } \\
\text { [number of day] }\end{array}$ & $\begin{array}{l}\text { The day closing } \\
\text { ice-free passage } \\
\text { [number of day] }\end{array}$ \\
\hline $\begin{array}{l}\text { Departure } \\
\text { from Providenya }\end{array}$ & & & & 233.0 & \\
\hline Bering Strait & 170 & 16 & 0.44 & 233.4 & 332 \\
\hline De Long Strait & 213 & 12 & 0.74 & 234.1 & 302 \\
\hline \multicolumn{6}{|c|}{ Awaiting till next sea has ice-free zone passage } \\
\hline \multicolumn{4}{|c|}{ Departure from entrance to De Long Strait } & 252.0 & \\
\hline Laptev Strait & 748 & 12 & 2.60 & 236.7 & 271 \\
\hline Vilkitsky Strait & 618 & 12 & 2.15 & 238.8 & 276 \\
\hline Cape Zhelanya & 599 & 12 & 2.08 & 240.9 & 357 \\
\hline Arrival at Murmansk & 252 & 16 & 0.66 & 242.9 & \\
\hline Port and cargo operati & ns [days] & & 3 & & \\
\hline \multicolumn{6}{|c|}{ Second leg (Eastward) — Total distance $3128 \mathrm{NM}$} \\
\hline Location & Distance & $\begin{array}{c}\text { Planned } \\
\text { speed } \\
\text { [knots] }\end{array}$ & $\begin{array}{c}\text { Days } \\
\text { of } \\
\text { passage }\end{array}$ & $\begin{array}{c}\text { Arrival date } \\
\text { of passage } \\
\text { [number of day] }\end{array}$ & $\begin{array}{l}\text { The day closing } \\
\text { ice-free passage } \\
\text { [number of day] }\end{array}$ \\
\hline $\begin{array}{l}\text { Departure } \\
\text { from Murmansk }\end{array}$ & & & & 245.9 & \\
\hline Cape Zhelanya & 780 & 16 & 2.03 & 247.9 & 357 \\
\hline Vilkitsky Strait & 599 & 12 & 2.08 & 250.0 & 276 \\
\hline Laptev Strait & 618 & 12 & 2.15 & 252.1 & 271 \\
\hline De Long Strait & 748 & 12 & 2.60 & 254.7 & 302 \\
\hline Bering Strait & 213 & 12 & 0.74 & 255.4 & 332 \\
\hline Arrival at Providenya & 170 & 16 & 0.44 & 255.8 & \\
\hline
\end{tabular}

\section{ALGORHITM FOR DETERMINING SCHEDULE OF PLANNED VESSELS VOYAGES}

Based on the presented analyzes, calculations and relationships the algorithm for design of schedule of planned voyage of vessels without ice-strengthened 
hulls on the NSR was created to the criterion of time frame (time window) of ice-free passage zone. This algorithm is a decision support system. It is presented in the form of flowchart (Fig. 5 and 6). The algorithm consists of two parts. First part is the calculation panel (Fig. 5). Here are designated values of parameters that serve for calculation of transit time and date of arrival at the nodal point. The calculation panel is also part of the decision-making loops.

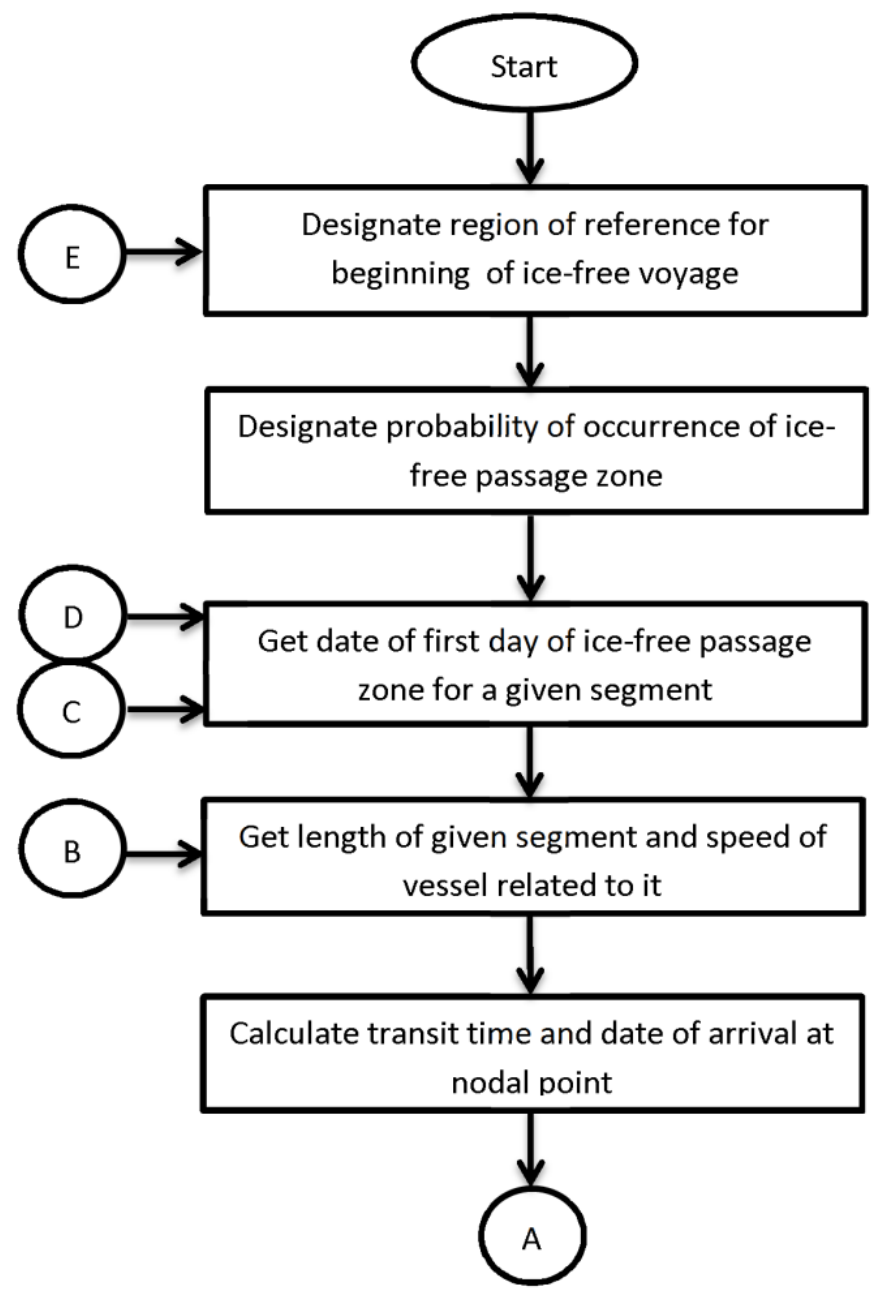

Fig. 5. Flowchart of decision support system for voyage planning on the NSR calculation panel 


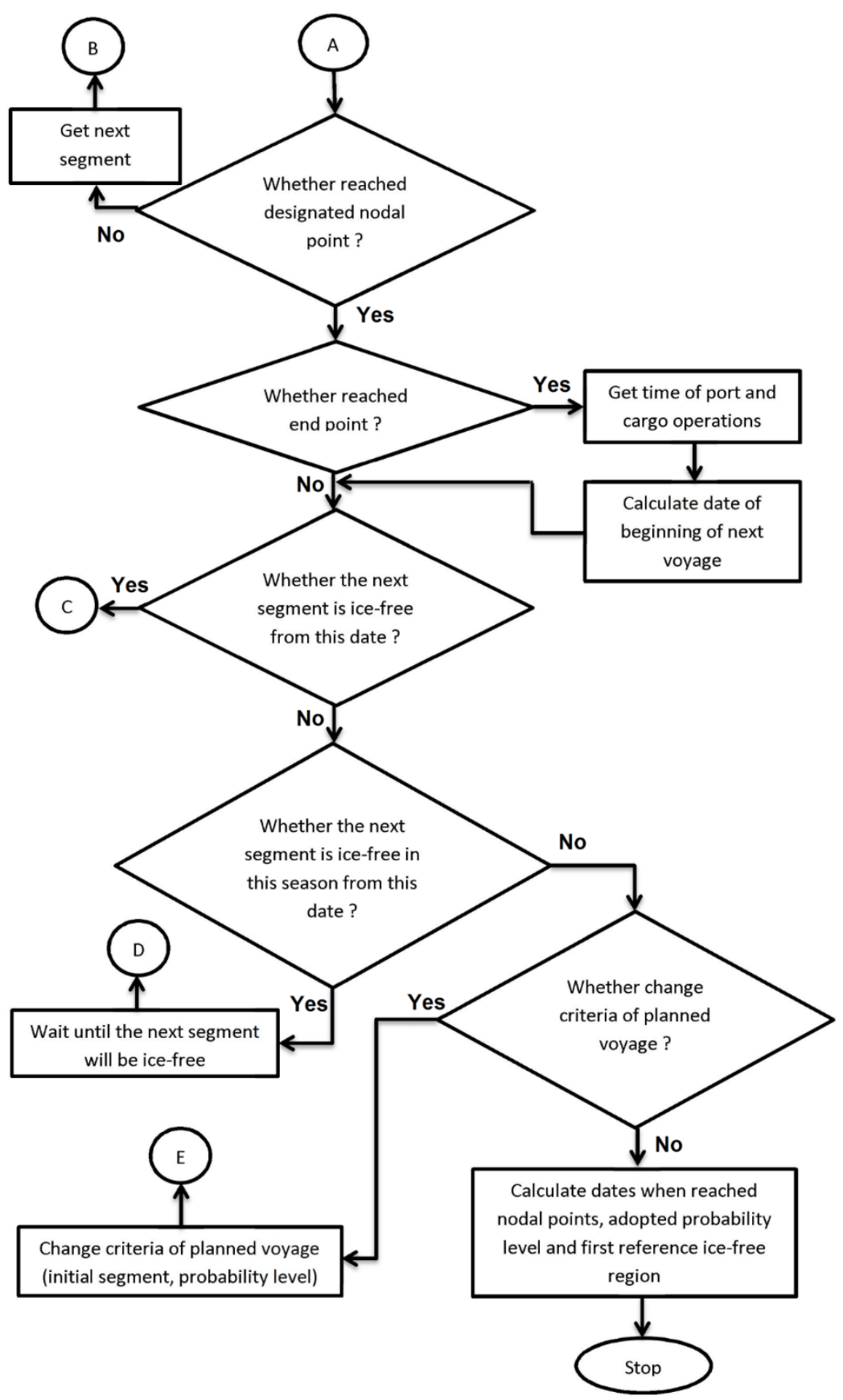

Fig. 6. Flowchart of decision support system for voyage planning on the NSR decision making panel 
The decision-making loops are commenced on conditional (decision-making) sections related to completing sections of the leg, reaching nodal point, reaching end point, availability of ice-free days for continuing vessel voyage on particular leg or particular navigation season, required waiting for ice-free passage zone and required changes of criteria for planned voyage leg. These criteria are dates of reached nodal points, dates of closing days that limiting navigation season for the vessels, adopted probability level and first ice-free of reference region that serve to determine the start date for calculation of predetermined consecutive vessel voyages option. The action of decision-maker is required in the 'required changes of criteria' conditional section and in the calculation panel on start of the procedure.

The use of presented in the work method of planning schedule of consecutive transit voyages of the vessel without ice-strengthening through the NSR is reliable in relation to ice conditions affecting the ice limitations of the vessels without ice-strengthening due to use statistical data for enough long period of eight latest years of accelerated climate change. It can be used for the initial voyage planning, that covers the period from 6 months till 1 month before commencement of navigation season. The proposed decision support algorithm can be used for estimation of time frame (time window) for transport of cargo on the NSR by means of vessels without ice strengthening. With thus received profitability evaluation (planned quantity of consecutive voyages), the person in charge of a vessel can make an independent decision based on safety and economic priorities determined in accordance with his knowledge, experience and actual available information on the existing ice and navigational circumstances.

\section{CONCLUSIONS}

The work discusses the possibility to predict quantity of consecutive transit voyages without ice-strengthening through the Northern Sea Route. Many uncertainties make safe and efficient voyages planning through the NSR difficult to predict. The probability approach including cumulative distribution function was used to solve the problem. The concept of 'ice-free passage zone' linking adjacent seas was introduced. The dates of first and last day of ice-free passage zone for particular seas of the Russian Arctic were determined from the analysis of the daily maps of ice cover for the years 2008-2015. 
The statistical data used for analysis were enough long to avoid misleading due to short term anomalies from the trend. Statistical data used in the work contained latest 8 years it means represented well the recent trends in accelerated climate change. Assumed, the use of cumulative distribution function as a probabilistic method in the evaluation of the possibility of vessel passage in the ice-covered regions seem to be more flexible, more synthetic in use and retaining continuous variation of studied parameters than the method of average value and multiple discrete changes of standard deviation. The dates of opening (ice-free) and closing (ice-closed) of particular seas were determined.

Found, that is possible to calculate the number of consecutive voyages when using developed decision supporting algorithm. It allows also to compare the results of planned voyages under option 'first leg Eastward' and 'first leg Westward' or compare the results of planned voyages with different input criteria. These criteria are dates of reached nodal points, dates of closing days that limiting navigation season for the vessels, adopted probability level and first reference ice free region that serve to determine the start date for calculation of predetermined consecutive vessel voyages option.

Developed algorithm is a decision support system. It can be used for the initial voyage planning, that covers the period from 6 months till 1 month before commencement of navigation season. One can use it for estimation of time frame (time window) for transport of cargo on the NSR by means of vessels without ice strengthening. With thus calculated planned quantity of consecutive voyages as profitability evaluation, the person in charge of a vessel can make an independent decision based on available calculations of ice-free voyages options, safety and economic priorities determined in accordance with his knowledge, experience and actual available information on the existing ice and navigational circumstances. The advantage of developed algorithm is its flexibility. It can be used on board vessels, in consulting companies and ship operator offices to design an ice navigation support system for the Northern Sea Route.

\section{REFERENCES}

[1] ACIA, Arctic climate impact assessment, Cambridge University Press, 2005.

[2] Dremlyug W. W., Nautical oceanography [in Polish, trans. M. Holec], Gdańsk 1974. 
[3] Pastusiak T., Accuracy of Sea Ice Data from Remote Sensing Methods, its Impact on Safe Speed Determination and Planning of Voyage in Ice-Covered Areas, 'International Journal on Marine Navigation and Safety of Sea Transportation', 2016, Vol. 10, No. 2, pp. 229-248.

[4] Pastusiak T., Competiviness of the Northern Sea Route in view of uncertain information, [in:] Natural Resources and Integrated Development of Coastal Areas in the Arctic Zone, Arkhangelsk 2016, pp. 360-368.

[5] Pastusiak T., Consistency of data presented on modern maps of ice cover in the Arctic, 'Polish Cartographical Review', 2016, Vol. 48, No. 2, pp. 55-66, [in: DeGruyter open].

[6] Pastusiak T., Nautical electronic maps of S-411 standard and their suitability in navigation for assessment of ice cover condition of the Arctic Ocean, 'Polish Cartographical Review', 2016, Vol. 48, No. 1, pp. 17-28, [in: DeGruyter open].

[7] Pastusiak T., Ship's route planning in ice infested areas of Northern Svalbard following ice charts made by remote sensing methods, [in:] Maritime Navigation and Safety at Sea Transportation. Miscellaneous problems in maritime navigation, transport and shipping, ed. A. Weintrit, London 2015, pp. 181-192.

[8] Pastusiak T., The Northern Sea Route as a shipping lane. Expectations and Reality, Springer International Publishing, 2016.

[9] Petrov M. K., Navigation in ice [in Russian], Morskoy Transport, Moscow 1955.

[10] Rodrigues J., The rapid decline of the sea ice in the Russian Arctic, 'Cold Regions Science and Technology', 2008, Vol. 54, pp. 124-142.

[11] Rodrigues J., The increase in the length of the ice-free season in the Arctic, 'Cold Regions Science and Technology', 2009, Vol., 59, pp. 78-101.

Received September 2016

Reviewed December 2016

\section{TADEUSZ PASTUSIAK}

Gdynia Maritime University

Jana Pawła II 3 Str., 81-345 Gdynia, Poland

e-mail: tadeusz.pastusiak@wp.pl

\section{STRESZCZENIE}

W artykule omówiono możliwości tranzytu statków bez wzmocnień lodowych kadłuba północną drogą morską (PDM). Najwięcej niepewności dotyczy warunków hydrometeorologicznych, głównie pokrywy lodowej w rosyjskiej części Arktyki, która podlega dynamicznym zmianom w czasie i przestrzeni. Trudno przewidzieć bieżące warunki lodowe, w przedziale jednego miesiąca, tym bardziej zaś z dużym wyprzedzeniem. Statystyczne 
dane historyczne dziennych zmian oraz zmian rocznych wykazują znaczny rozrzut wartości. Autor przeanalizował liczbę dni bezlodowych na poszczególnych morzach PDM w ostatnich ośmiu latach — od 2008 do 2015 roku. Wyniki te mogą być wykorzystane do szacowania przedziału czasu (okna czasowego) dla przewozu ładunków północną drogą morską statkami bez wzmocnień lodowych kadłuba. Statystyczne zależności dni wolnych od lodu zostały wykorzystane do opracowania metody wspierającej decyzje związane z planowaniem podróży statku z uwzględnieniem okna czasowego żeglugi bezlodowej na poszczególnych morzach PDM. 